\title{
Gendering COVID-19: Impact of the Pandemic on Women's Burden of Unpaid Work in India
}

\author{
Priyanshi Chauhan ${ }^{1}$
}

Accepted: 3 October 2020 / Published online: 24 October 2020

(c) Springer Science+Business Media, LLC, part of Springer Nature 2020

\begin{abstract}
The COVID-19 pandemic has exacerbated the already existing gender inequalities with substantial implications on women. With the closure of offices and educational institutions, and the emerging norm of work from home and online education, along with the lack of services of domestic worker, the need to perform unpaid chores in the household has increased. Simultaneously, the requirements of social distancing and sanitization have created new unpaid chores. Owing to the sexual division of labour, and gendered roles and social norms of performing domestic and care work, the burden of unpaid work falls disproportionately on women. In this context, the objective of the paper is to study the impact of COVID-19 on time spent on unpaid work and the underlying gender differences in the urban centres in India. Specifically, the paper will do a comparative analysis of the gender differences in time spent on unpaid work before and during the lockdown, and analyse the reasons for the same.
\end{abstract}

Keywords COVID-19 · Gender equality · Unpaid work · Gender roles · Lockdown

\section{Introduction}

The COVID-19 pandemic has wreaked havoc across the world and brought the world to a standstill with unprecedented changes in our society and economy. As has been the case, the novel coronavirus spread with such a speed and intensity across the world due to the interconnectedness of the globalized world that most countries imposed temporary shutdowns as a strategy to contain its spread. The Government of India imposed a nationwide lockdown on 24 March 2020, initially for 21 days only, which was eventually extended till 30 May in various phases. The impacts of the lockdown have been disruptive and changed the way in which humans perform

Priyanshi Chauhan

priyanshi8393@gmail.com

1 Centre for South Asian Studies, Jawaharlal Nehru University, Room 219, Delhi 110067, India 
their daily activities and go about their routine lives. Such impact has however not been the same across all social groups, with the most vulnerable and marginalized groups being affected differently due to the already existing social inequalities [13]. Specifically, the lockdown has widened the existing gender inequalities and limited the opportunities for women [25, 28].

One of the ways in which the pandemic has affected women differently than men is through increased burden of unpaid work. Owing to the sexual division of labour, and gendered roles and social norms of performing domestic and care work in a household, the burden of unpaid work falls disproportionately on women. Such tasks are time-consuming and physically tiring, and subject women to time poverty, ${ }^{1}$ leaving little or no time for them to undertake productive activities like education or employment, or leisure. The pandemic has worked to exacerbate the already existing gendered nature of unpaid work at home [25, 28]. With the closure of offices and educational institutions, and the simultaneously emerging norm of work from home and online education, along with the lack of services of domestic workers, the need to perform unpaid chores like cooking, cleaning, washing, child care among others by household members has increased [3]. For working women, the lockdown has meant the collapse of the demarcation of their professional spaces and domestic life which has led to the simultaneous performance of their office work and household responsibilities.

In this context, the objective of the paper is to study the impact of COVID-19 on time spent on unpaid work and gender differences for the same in the urban centres in India. Specifically, the paper will do a comparative analysis of the gender differences in time spent on unpaid work before and during the lockdown. Furthermore, the paper will study the gendered impact of lockdown on unpaid labour of women on various parameters like marital status, employment status, income levels and average weekly office hours. Finally, the paper will analyse the reasons for the observed gendered differences in unpaid household chores.

\section{Gender Dimension of Unpaid Work}

The term unpaid work, as given by the International Labour Organization [15, p. 40], is the "non-remunerated work carried out to sustain the well-being and maintenance of other individuals in a household or the community, and it includes both direct and indirect care (i.e. routine housework)'. The ILO estimates show that time spent in unpaid work accounted for ' 16.4 billion hours per day, with women contributing more than three-fourths of the total' which is 'equivalent to 2.0 billion people working on a full-time basis without pay' [15, p. 43]. In India, women spend an average of $351.9 \mathrm{~min} /$ day on unpaid work as compared to an average of $51.8 \mathrm{~min} /$

\footnotetext{
1 Time poverty is the burden of competing claims on an individual's time that reduce their ability to make unconstrained choices in how they allocated their time leading to trade offs among various tasks. The burden of unpaid work causes time poverty as it prevents women from participating in paid labour and social activities, thus feeding back to their low status [9, pp. 106-107].
} 
Table 1 Time spent by gender on unpaid and paid work in India. Source: OECD [20]

\begin{tabular}{lclc}
\hline $\begin{array}{l}\text { Time spent (minutes } \\
\text { per day) }\end{array}$ & Unpaid work & Paid work & Total \\
\hline Men & 51.8 & 390.6 & 442.3 \\
Women & 351.9 & 184.7 & 536.6 \\
\hline
\end{tabular}

day by men [20]. In addition, data show that time spent on total paid and unpaid work by women in India is $536.6 \mathrm{~min} /$ day as compared to an average of $442.3 \mathrm{~min} /$ day being spent by men [20]. This implies that for women engaged in paid employment, the drudgery of unpaid work ${ }^{2}$ is so high that they work longer than men. Overall, the data highlight the gendered nature of unpaid work and shows that the burden of such activities falls disproportionately on women (Table 1).

\section{Theoretical Understanding}

There are two theoretical strands in the existing literature that explain the gendered nature of unpaid work and its disproportionate burden on women, namely the economic perspective and the gender perspective. The economic perspective emphasizes the principles of rationality and comparative advantage. Accordingly, it states that women's engagement in unpaid labour depends on the comparative advantage relative to the paid work which can be changed with changes in various factors like educational attainment and wages [24]. Within the economic perspective, there are two models, namely the unitary model and intra-household bargaining model that explain the burden of unpaid work. As originally given by Becker [4], the unitary model assumes household as the basic unit of analysis with common preferences and common utility curve of all members. The argument in the unitary model leads to role specialization where one partner invests more time in producing income and the other spends more time in non-market work [18]. The feminist economists however reject the unitary model as it does not consider the role of gender as a factor in different preferences for women $[2,8,22]$. The basis for this is that gender plays a significant role in determining power relations within a household where men are often more privileged than women, and the allocation of resources is in favour of men leaving women worse-off who could be effectively in poverty, even when the household aggregates indicate otherwise [8, 26]. In addition to determining the intra-household allocation of resources, gender also affects the decision making power and responsibilities within a household [2, 8]. As such, households are sites where gender roles are both produced and performed through various means like the sexual division of labour. Going further, the assumption of unitary models that the household is a rational unit is criticized as it not only neglects the gendered nature of household and the consequent inequalities in resource distribution

\footnotetext{
2 The term 'drudgery of unpaid work' in the paper attributes domestic work as not only hard and menial, but also considers its implications on women's overall well-being including the social, economic and political dimensions as is subsequently discussed in the paper.
} 
but also justifies them in "favour of economic rationality" [17, p. 28], thereby seeing intrahousehold power dynamics and inequalities across genders as excusable and even preferable. According to the intra-household bargaining models, the partner with greater resources, who are generally men owing to power dynamics of gender, will use these resources to avoid unpaid work [18]. The gender perspective derives from the sociological understanding of gender as a power relation. Accordingly, the approach emphasizes reinforcing masculine and feminine behaviour through unpaid labour. Specifically, by avoiding unpaid work men tend to display masculinity whereas performing unpaid household chores is considered integral to being an 'ideal' wife or mother [21, 27]. Interestingly, this is evident in situations where both men and women in a household are engaged in full time employment and earn equal incomes, there is a tendency for women to do more household work [5, 6, 12]. This is because, women making more money than the husband is considered as a deviance from the gender norm where a husband is to provide for the household, and therefore to neutralize this deviance women take more responsibility of the unpaid household chores, thereby reinforcing the gender norms [12].

\section{Implications of Burden of Unpaid Work on Women}

Since the burden of unpaid work is relatively greater on women as compared to men, it raises various concerns for them. The chores that fall into the category of unpaid labour are physically exerting and time consuming. As such, the unpaid work of women takes away most of their time and subjects women to time poverty, leaving little or no time for them to engage in productive activities like education and paid employment $[1,7,10]$. In India, women's labour force participation is dismal and has been showing a declining trend for more than a decade. According to the World Bank data, female labour force participation ${ }^{3}$ has decreased from $32 \%$ in 2005 to $21 \%$ in 2019 [29]. Simultaneously, women's time poverty has increased manifold [9, p. 101], despite the drop in their labour force participation, clearly suggesting that women experience extreme time poverty due to their responsibilities of unpaid labour. Consequently, lack of personal income affects their economic status, financial independence, bargaining power and decision making within the household, thereby affecting the intra-household distribution of resources in favour of men as guided by the power dynamics of gender relations. Furthermore, women's lower labour force participation also disincentivizes investment in education and skill development of girls and young women, and they further get pushed into undertaking unpaid labour. Thus, disproportionate burden of unpaid work pushes women out of the labour force which not only affects their financial status but also makes education and skill upgradation less attractive which reduces their opportunities of participating in formal economy, therefore raising equity concerns for women's participation in the process of development. Simultaneously, the designation of household chores as 'women's work' does not include the element of choice and is instead

\footnotetext{
3 The data on labour force participation rate is given as a proportion of the female population and is the proportion of the population ages 15 and older that is economically active: all people who supply labor for the participation of goods and services during a specified period [29].
} 
governed by the norms of gender division of labour and norms, and feeds into the existing power relation across genders [1, p. 22].

For women in paid employment, the drudgery of unpaid work is so high that they work longer than men owing to the triple burdens of unpaid work, reproductive work and paid employment. Consequently, there are only limited opportunities for social and political participation, which has significant bearing for their empowerment, and for leisure which affects their overall well-being [10]. This also affects their opportunities for career advancement, as women's participation in paid work reduces the time spent on unpaid work but less than proportionally as compared to the increase in time in paid work, thereby effectively increasing the number of hours women spend working which is often compensated from the time spent for leisure, sleep, or personal care activities $[1,11]$.

Finally, the unpaid labour performed by women in not accounted for in the national accounting systems, and are therefore excluded from the realm of policy making [14, p. 70]. Efforts to integrate women in the development process to make it inclusive have not considered the drudgery of unpaid work on women. For instance, the much recognized 'efficiency approach' that calls for integration and increased participation of women in the development process on grounds of costs of excluding women from the formal economy and the resulting inefficiencies in the markets, seeks to bring women into the ambit of development without considering the impact on their overall well-being. The literature highlights that such development, though inclusive, is bound to put stress on women, increase their drudgery and affect their overall well-being [23, p. 7; 19].

\section{Methods}

The research follows a qualitative approach and primary data is collected in two stages. In the first stage, a survey is conducted with the objective to understand patterns of time spent on household chores for men and women, both before and during the lockdown. At the second stage, semi-structured interviews are conducted with the objective to understand the reasons for responses received in stage one. Since the objective is to do a gender analysis of the impact of COVID-19 on unpaid work, the unit of analysis for the research is the individual, with focus on two genders, namely men and women. The chores included in the unpaid work comprise of cleaning the house, cleaning the dishes, cooking, childcare, elderly care and laundry among others. Non-probability sampling techniques were used to make decision regarding the sample population. Specifically, convenience sampling techniques and judgemental sampling techniques were used for the purpose of the survey and interviews respectively. For interviews, a sub-sample from stage one was taken based on the characteristics like marital status, employment status, use of services of domestic help, and the responses received on change in time spent on unpaid chores during the lockdown. The total sample size for survey comprised of 100 and 20 individuals for stage one and two respectively. The geographical scope of the research is limited to urban and semi-urban areas in India. Owing to the conditions of lockdown and the social distancing norms, the data have been collected through virtual mode only, via 
Table 2 Characteristics of the survey respondents

\begin{tabular}{|c|c|c|c|}
\hline Characteristics & $\begin{array}{l}\text { Men (percentage of } \\
\text { population) }\end{array}$ & $\begin{array}{l}\text { Women (percentage of } \\
\text { population) }\end{array}$ & $\begin{array}{l}\text { Percentage of } \\
\text { total population }\end{array}$ \\
\hline \multicolumn{4}{|l|}{ Size } \\
\hline Total & 43 & 57 & 100 \\
\hline \multicolumn{4}{|l|}{ Marital status } \\
\hline Married & 35 & 40 & 75 \\
\hline Unmarried & 8 & 17 & 25 \\
\hline \multicolumn{4}{|l|}{ Age group } \\
\hline $18-30$ & 14 & 22 & 36 \\
\hline $30-45$ & 17 & 25 & 42 \\
\hline $45-60$ & 12 & 10 & 22 \\
\hline \multicolumn{4}{|l|}{ Education } \\
\hline Class 12 & 1 & 2 & 3 \\
\hline Graduate & 17 & 8 & 25 \\
\hline Post graduate & 24 & 40 & 64 \\
\hline M.Phil. and above & 1 & 7 & 8 \\
\hline \multicolumn{4}{|l|}{ Employment status } \\
\hline Employed & 41 & 34 & 75 \\
\hline Unemployed & 2 & 23 & 25 \\
\hline \multicolumn{4}{|c|}{ Domestic help before the lockdown } \\
\hline Yes & 38 & 49 & 87 \\
\hline No & 5 & 8 & 13 \\
\hline
\end{tabular}

the internet and telephonic conversation only. Further, the survey was conducted in English language, and the interviews were conducted in both English and Hindi language based on the preferences of the interviewee.

\section{Findings}

Details of the descriptive characteristics of the respondents who participated in the survey are presented in Table 2. Out of the total sample population of 100 respondents for the survey, $43 \%$ are men and $57 \%$ are women. Based on the marital status, $75 \%$ of the population is married and $25 \%$ is unmarried. The employment status of the respondents is such that $75 \%$ of them are employed and $25 \%$ are unemployed. Sixty-four percent of the respondents have stated post-graduation as their highest qualification, followed by $25 \%$ being graduates, $8 \%$ with M.Phil. and above, and $3 \%$ who studied till class 12 . Based on the educational qualifications and the average monthly income, all the respondents to the survey are from the middle class. Furthermore, $87 \%$ of the total population, and approximately $88 \%$ and $86 \%$ of men's and women's population respectively availed the services of domestic workers before the lockdown to perform multiple household chores like cooking, cleaning, child care, elderly care, laundry among others which are otherwise unpaid when 


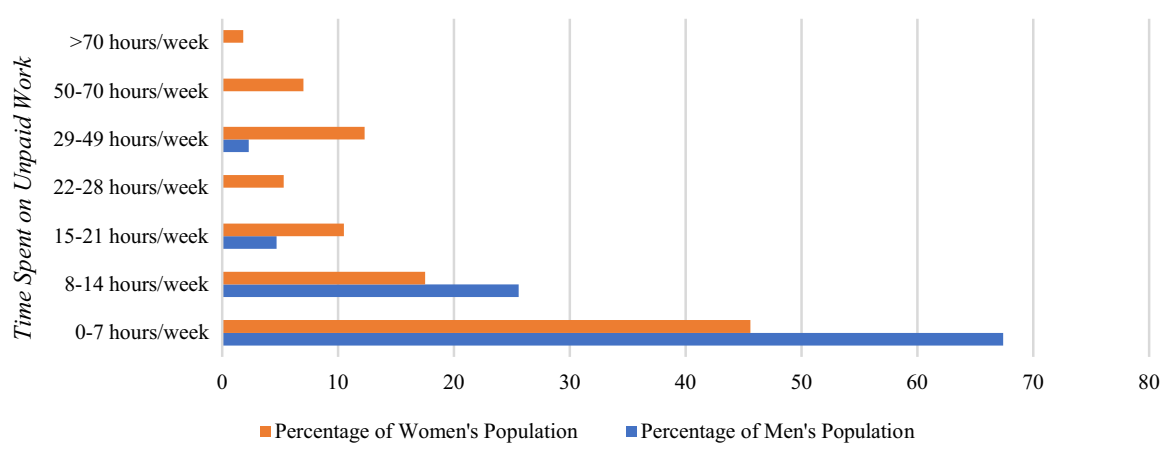

Fig. 1 Gender-wise time spent on unpaid work before the lockdown

performed by a member of the household. It should be noted that the category of 'unemployed men' includes only two respondents, and therefore does not provide sufficient information regarding their time-use patterns and how the lockdown has affected their burden of unpaid labour.

\section{Burden of Unpaid Household Chores Before the Lockdown}

\section{Women Spent Relatively More Time on Unpaid Chores}

Figure 1 shows the comparative burden of household chores on men and women, and is consistent with the theoretical exposition that the burden of unpaid work fell disproportionately on women. ${ }^{4}$ It can be observed from Fig. 1 that the highest percentage of both men and women spent a maximum of $14 \mathrm{~h} /$ week to perform unpaid work. However, more men spent up to $14 \mathrm{~h} /$ week as compared to women. Specifically, 93\% men spent a maximum of $14 \mathrm{~h} /$ week on unpaid work as compared to $62 \%$ women before the lockdown. Furthermore, there is a virtual absence of men from the higher time intervals spent on domestic work as compared to a significant presence of women in these time intervals. Approximately, 5\% women spent 22-28 h/week on domestic chores as compared to zero men, and $12.3 \%$ women spent 29-49 h/week on domestic chores as compared to $2.3 \%$ men. Interestingly, no man spent more than $50 \mathrm{~h} /$ week on unpaid work as compared to approximately $9 \%$ women. This is significant considering the fact that spending more than $50 \mathrm{~h} / \mathrm{week}$ on unpaid work is greater than the maximum limit of $48 \mathrm{~h} /$ week for paid employment set by the law but do not get remunerated for the same. Figure 1, therefore clearly highlights that despite a comparable use of the services of domestic workers for domestic chores in the survey sample, it is women who bear a higher and disproportionate burden of unpaid household chores as compared to men.

\footnotetext{
${ }^{4}$ For detailed survey results, see "Appendix", Table 3.
} 


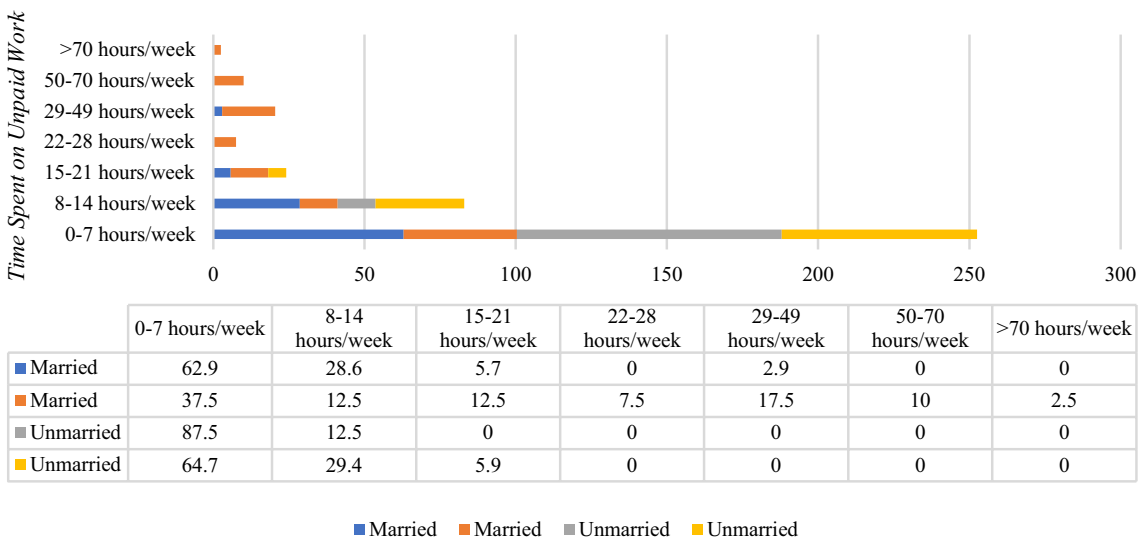

Fig. 2 Gendered burden of unpaid work based on marital status

\section{Marital Status as a Determinant: Married Women Share the Highest Burden of Unpaid Chores}

Differences in the burden of unpaid work are observed based on the marital status of the respondents. To assess the same, the respondents have been categorized as -married men, married women, unmarried men and unmarried women. ${ }^{5}$ As shown in Fig. 2, the highest percentage of population from all the four categories spent up to $7 \mathrm{~h}$ /week on unpaid chores. However, there are differences in the percentage of population of each category spending $0-7 \mathrm{~h}$ per week on such tasks, with the least percentage of married women $(37.5 \%)$, followed by married men $(63 \%)$ and unmarried women $(65 \%)$ and the highest percentage of unmarried men $(88 \%)$. All unmarried men spent only a maximum of $14 \mathrm{~h} /$ week on household chores. Simultaneously, $100 \%$ of unmarried women and $97 \%$ of married men spent a maximum of $21 \mathrm{~h} /$ week on household chores. This stands in stark contrast to the burden of unpaid household chores on married women, with $18 \%$ spending $29-49 \mathrm{~h} /$ week, and $12.5 \%$ spending more than $50 \mathrm{~h} /$ week on domestic chores in the household. Marital status is therefore a key determinant of the burden of unpaid labour in a household, with survey respondents showing that married women share the highest burden.

\section{Employment Status as a Determinant: Unemployed Women Share the Highest Burden of Unpaid Chores}

Other than the marital status, the gendered burden of unpaid domestic chores also depends on the employment status of each individual. As shown in Fig. 3, approximately $68 \%$ of employed men and $56 \%$ of employed women spent a maximum of $7 \mathrm{~h}$ /week on unpaid work, as compared to only $30 \%$ of unemployed women. ${ }^{6}$ Ninetyfive percent of employed men and $80 \%$ of employed women spent a maximum of

\footnotetext{
5 For detailed survey results, see "Appendix", Tables 4 and 5.

${ }^{6}$ For detailed survey results, see "Appendix", Tables 6 and 7.
} 


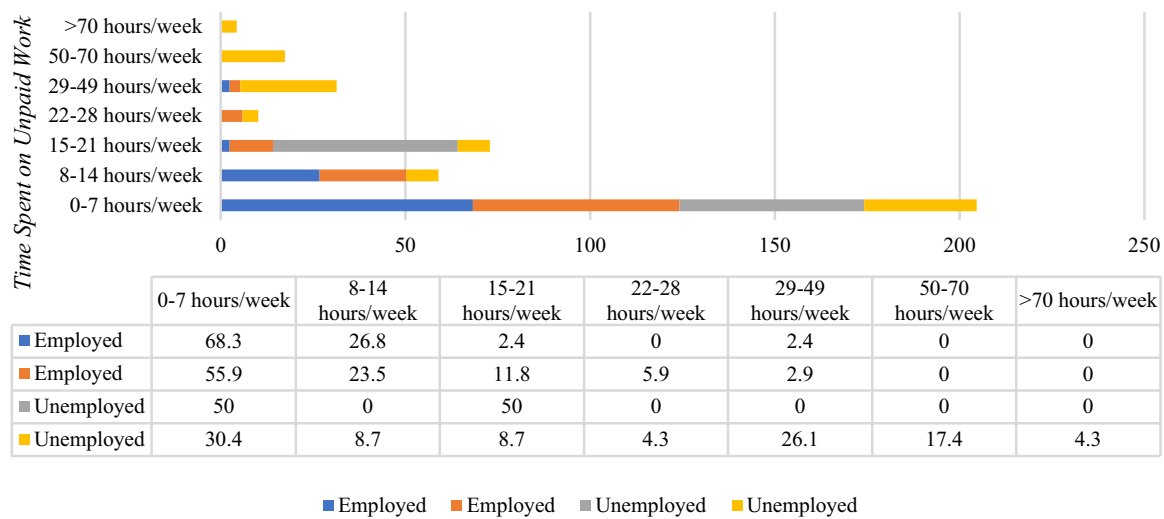

Fig. 3 Gendered burden of unpaid work based on employment status

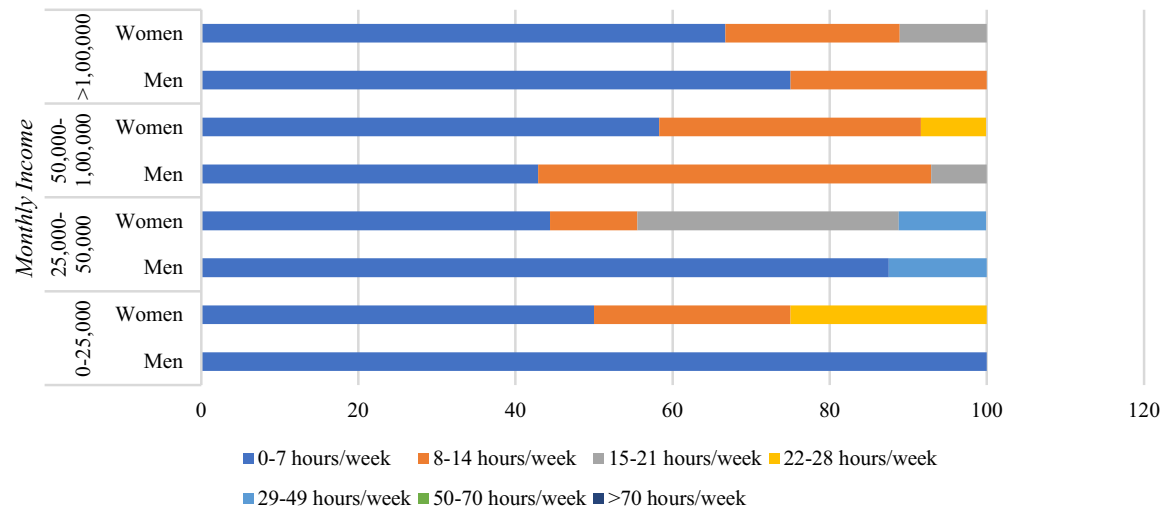

Fig. 4 Gendered burden of unpaid work based on monthly income

$14 \mathrm{~h} /$ week to household chores, thereby highlighting similar patterns in time spent on household work before the lockdown, though favouring employed men. Contrasting this, approximately $26 \%$ and $22 \%$ of unemployed women spent $29-49$ h/week and more than $50 \mathrm{~h} /$ week respectively on unpaid work. In the unemployed women category, the respondents can be further categorized as students and housewives/ homemakers. It was found that $100 \%$ of unemployed women who are students dedicate a maximum of $14 \mathrm{~h} /$ week to unpaid work, whereas approximately $67 \%$ unemployed women who identify themselves as housewives/homemakers contribute more than $50 \mathrm{~h} /$ week. Therefore, based on the employment status, it is the unemployed women, more specifically, the housewives/homemakers who had the highest burden of unpaid work before the lockdown. It should also be noted that all the respondents 


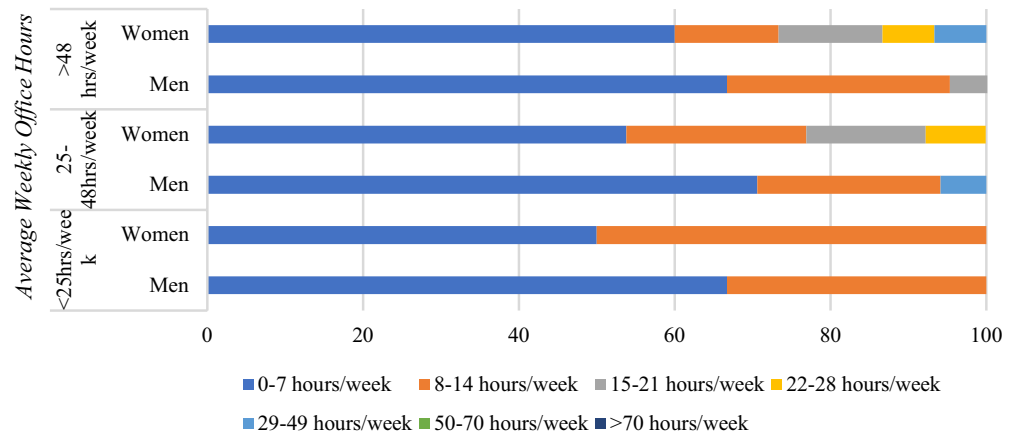

Fig. 5 Gendered burden of unpaid household chores based on average weekly hours

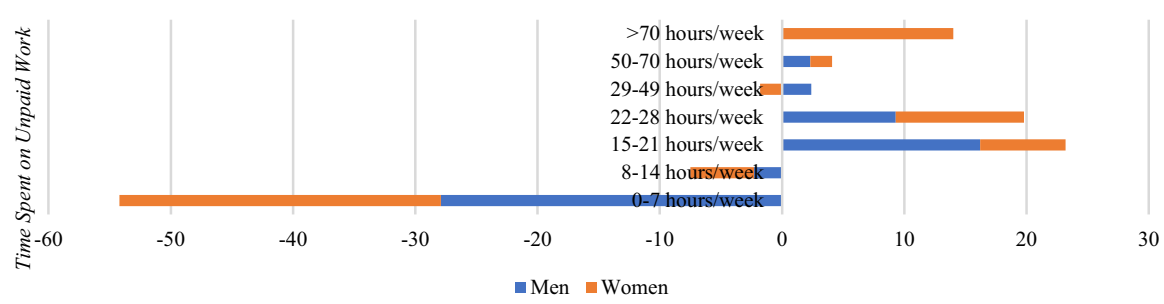

Fig. 6 Gender-wise percentage change in the time spent on unpaid work

who identified themselves as 'housewives/homemaker' are married, meaning that the employment status and marital status intersect, and affect women's burden of unpaid labour in a household. For employed respondents, the gender-wise burden of unpaid labour is similar across different income groups, and average office hours as shown in Figs. 4 and 5 respectively, and these variables did not significantly affect the burden of unpaid labour across genders in the pre-COVID period. ${ }^{7}$

The following inferences can be drawn from the above for the burden of unpaid work and its gendered nature before the lockdown. First, despite a similar and comparable use of the services of domestic workers in the sample population, the burden of unpaid work fell disproportionately on women. Second, marital status and employment status are key determinants of time spent on domestic work. Third, in the context of marital status being a variable, married women share the highest burden of unpaid labour at home. Fourth, based on the employment status, it is the unemployed women, particularly those who identify themselves as housewives/ homemakers, who share the highest burden of domestic work. Fifth, for employed individuals, no significant gendered differences in the pattern of sharing the load of household chores is found based on their average monthly income or average weekly office hours.

\footnotetext{
7 For detailed survey results, see "Appendix", Tables 8 and 10.
} 


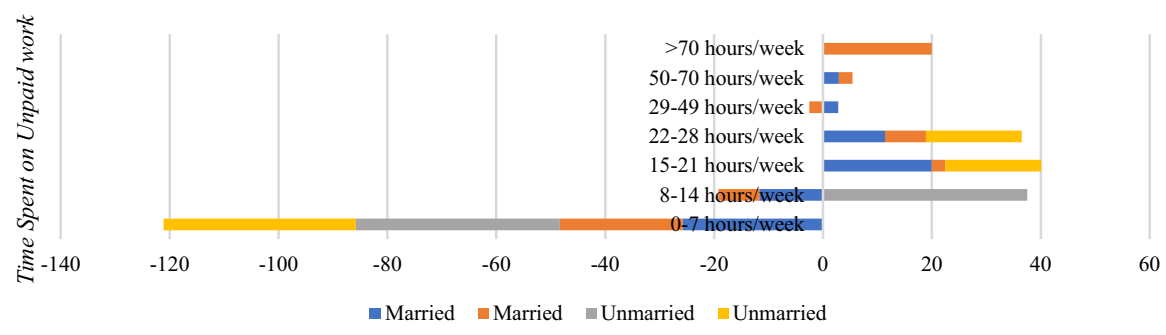

Fig. 7 Percentage change in gendered burden of unpaid household chores based on marital status

\section{Burden of Unpaid Household Chores During the Lockdown}

\section{Increase in Burden of Unpaid Work for All but More for Women}

During the lockdown, $81 \%$ of the total survey population reported to avail no services of the domestic workers as compared to $13 \%$ before the lockdown. Therefore, the domestic work including cleaning, cooking, laundry, child care, elderly care among others which were earlier performed by the domestic workers for income, are now performed by the household members without any remuneration. Therefore, the burden of unpaid work during the lockdown increased for all. A comparison of the time spent on such tasks before and during the lockdown in terms of change in percentage points is shown in Fig. $6{ }^{8}$ Highest decrease has been observed for the percentage of population spending up to $7 \mathrm{~h} /$ week on unpaid work during the lockdown for both men (27.9 percentage points) and women (26.3 percentage points). However, the disparity across genders has increased. Approximately, only $19.3 \%$ of women now spend a maximum of $7 \mathrm{~h} /$ week on unpaid household chores as compared to $39.5 \%$ men during the lockdown. Furthermore, for men the highest increase in population of 16.2 percentage points is observed in the time interval of (15-21) $\mathrm{h} /$ week whereas highest increase for women of 14 percentage points has been observed for more than $70 \mathrm{~h} /$ week being spent on unpaid work. Interestingly, no man in the survey population spent more than $70 \mathrm{~h}$ on household tasks during the lockdown. It should be further highlighted that during the lockdown, $93 \%$ men dedicated up to $28 \mathrm{~h} /$ week on unpaid household responsibilities as compared to only $64.9 \%$ women. Simultaneously, $35 \%$ and $25 \%$ women spend more than $28 \mathrm{~h} /$ week and $50 \mathrm{~h} /$ week respectively on unpaid work during the lockdown as compared to $21 \%$ and $8.8 \%$ women before the lockdown. Therefore, the conditions of lockdown to contain the spread of COVID-19 has increased the burden of household work for all, but the responsibility has increased relatively more and disproportionately for women who were already spending more time in unpaid work than men before the lockdown.

\footnotetext{
${ }^{8}$ For detailed survey results, see "Appendix", Table 3.
} 

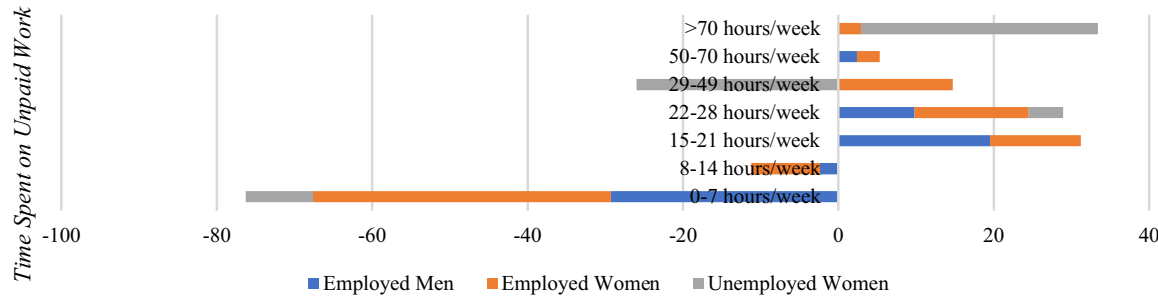

Fig. 8 Percentage change in gendered burden of unpaid work based on employment status

\section{Based on Marital Status, Married Women Witness the Highest Increase in Unpaid Work}

Based on the marital status, a comparison of time allocated to unpaid work before and during the lockdown, is shown in Fig. $7 .^{9}$ There has been a highest decrease in the percentage of population spending up to $7 \mathrm{~h}$ /week on unpaid work during the lockdown, being approximately 26 percentage points for married men, 23 percentage points for married women, 38 percentage points for unmarried men, and 35 percentage points for unmarried women. While the decline has been greater for unmarried individuals, it should be noted that the percentage of unmarried men and women spending a maximum of $7 \mathrm{~h} /$ week is $50 \%$ and $25 \%$ respectively, which is higher than that of married individuals. In addition, the data also highlight that the percentage of both married and unmarried men spending up to $7 \mathrm{~h} /$ week on unpaid work is greater than that of married and unmarried women. Furthermore, 100\% unmarried men spent up to $14 \mathrm{~h} /$ week on such tasks during the lockdown which is the same as before the lockdown, as compared to approximately $60 \%$ unmarried women. For married men, the highest increase in population of 20 percentage points and 11.4 percentage points has been observed in the time interval of (15-21) h/week followed by $(22-28) \mathrm{h} /$ week. All this is in stark contrast to the increase in the percentage of women who spent more than $70 \mathrm{~h} /$ week and has observed an increase of 20 percentage points during the lockdown. Not only has the increase been the largest, the highest percentage of married women, approximately $22.5 \%$, worked for more than $70 \mathrm{~h} /$ week. Before the lockdown, the highest percentage of married women worked maximum of $7 \mathrm{~h} /$ week on household chores. Interestingly, no men and unmarried women worked for more than $70 \mathrm{~h} /$ week during the lockdown. In addition, one-fourth of married women spent more than $50 \mathrm{~h} /$ week to unpaid household activities as compared to zero unmarried men and women, and only $3 \%$ married men.

\footnotetext{
${ }^{9}$ For detailed survey results, see "Appendix", Tables 4 and 5.
} 


\section{Based on Employment Status, Unemployed Women (Homemakers) Witness the Highest Increase in Unpaid Work}

Based on the employment status, Fig. 8 shows that there has been a highest decrease in the percentage of population spending a maximum of $7 \mathrm{~h} /$ week on household tasks during the lockdown, for both employed men (29.3 percentage points) and employed women (38.3 percentage points). ${ }^{10}$ However, the percentage of men (39\%) spending a maximum of $7 \mathrm{~h}$ /week is more than double than that of women (17.6\%) during the lockdown. For employed men, the highest increase of 19.5 percentage points is observed in the 15-21 h/week time interval as compared to that of employed women of 14.7 percentage points in 22-28 h/week and 29-49 h/week each spent on unpaid work. Furthermore, approximately $23 \%$ employed women spent more than $29 \mathrm{~h} /$ week on household chores as compared to only $5 \%$ employed men during the lockdown. The case of unemployed men is not considered due to lack of sufficient data. Unemployed women show a very marginal decrease of 8.7 percentage points in the 0-7 h/week interval. This can be attributed to their already lower presence of $30.7 \%$ in the given time interval before the lockdown as compared to approximately $68 \%$ and $56 \%$ for employed men and employed women respectively. In addition, unemployed women witness the highest decrease of 26 percentage points in the 29-49 h/ week interval during the lockdown and highest increase of 30.5 percentage points for those who spent more than $70 \mathrm{~h} /$ week on unpaid work. It has been observed that all those unemployed women who spent 29-49 h/week on domestic work before the lockdown now spent more than 70 h/week during the lockdown. Interestingly, a significant population of unemployed women also spent a maximum of $7 \mathrm{~h} / \mathrm{week}$ on household chores. It has been found that all the unemployed women respondents who spent less than $7 \mathrm{~h}$ /week on unpaid work are students, and all the unemployed women respondents who spent more than $70 \mathrm{~h} /$ week on unpaid work identify themselves as housewives/homemakers.

For the employed respondents, similar patterns were observed in the burden of unpaid labour for men and women across all income groups before the lockdown. However, during the lockdown, the burden of unpaid labour has increased more for women as compared to men across all income groups. ${ }^{11}$ For instance, in the highest income group for the survey of $>100,000 \mathrm{INR} /$ month, $33.3 \%$ women now spend $22-28 \mathrm{~h} /$ week on unpaid work as compared to $0 \%$ before. This is also significantly higher as compared to men in the same income group, only $6.25 \%$ of whom spend $22-28 \mathrm{~h} /$ week on domestic chores. Similarly, in the income group of 50,000-100,000 INR, 25\% and 8.3\% women spend 22-28 h/week and $>70 \mathrm{~h} /$ week on household chores respectively as compared to $0 \%$ men during the lockdown.

Similar observations have been made in the context of average weekly office hours, where there was no significant gendered burden of unpaid work before the lockdown. During the lockdown, the burden has increased for all, but disproportionately so for women. For instance, for the respondents whose average office hours are more than $48 \mathrm{~h} /$ week, lockdown has increased the percentage of such women spending 29-49 h/

${ }_{10}$ For detailed survey results, see "Appendix", Tables 6 and 7.
${ }^{11}$ For detailed survey results, see "Appendix", Tables 8, 9, 10 and 11. 
week on household chores to $26.7 \%$ as compared to $6.7 \%$ before the lockdown. Simultaneously, the percentage of men in the same interval of $29-49 \mathrm{~h} /$ week has been increased to $4.8 \%$ as compared to $0 \%$ before the lockdown. Similarly, for respondents whose average office hours are 25-48 h/week, lockdown has increased the percentage of women who spend 50-70 h/week and 29-49 h/week on household chores to $7.7 \%$ and $15.4 \%$ respectively during the lockdown from $0 \%$ before the lockdown. Interestingly, only 5.9\% men with same working hours spend 29-49 h/week on household chores and no man spends more than $49 \mathrm{~h}$ /week on such tasks during the lockdown.

In a nutshell, the lockdown has increased the burden of unpaid work for all members of the household. However, there are differences in the share of such burden across gender lines when explored within the household. First, despite an increase in the time spent for everyone on unpaid work, the burden has increased more for women. Second, marital status and employment status are key determinants of the gendered nature of such an increase of women's labour on unpaid chores during the lockdown. As such, the burden has increased the largest for married women and unemployed women, who already spent the highest time on domestic work even before the lockdown. Third, for unemployed women, it is those who identify themselves as the housewives/ homemakers who spent maximum time on unpaid household chores during the lockdown. Fourth, for the individuals who are employed, the burden has increased more for employed women. Fifth, based on changes in average monthly income and average weekly office hours, there was a similarity in trends on the burden of household labour for men and women before the lockdown. However, during the lockdown, stark differences are observed where women spend more time on household chores than men in the same income groups and average weekly office hours groups. Overall, women are more burdened across all parameters including marital status, employment status, average monthly income and office hours. It would be fair to say that the burden of unpaid work has increased for all, but increased more for women who were already responsible for such chores even before the lockdown, thus exacerbating the already existing inequalities.

\section{Gendered Experiences of Unpaid Work}

Based on the interviews conducted, it is observed that the COVID-19 pandemic and the consequent lockdown have created needs of social distancing, hygiene and care, and sanitization. Simultaneously, the lockdown has imposed new restrictions on the mobility of individuals with emerging norms of work from home, and online education, accompanied by no services of domestic workers to perform the household chores. The responsibility to perform these tasks both directly or indirectly facilitate them has fallen more on women as is discussed below:

\section{Online Work and Education}

Along with the restrictions on mobility, the COVID-19 pandemic has shifted the office spaces and classrooms to the homes of the people, meaning that individuals who would go out of their homes into the professional spaces for the purpose of 
income earning or educational opportunities now spend more time at home doing the same activities. Young people who were living away from their hometowns in pursuit of education and jobs have also returned to their homes due to the flexibility of performing these activities from within the house. This implies that the services including buying cooked meals and snacks, the entire process of cooking, and finally cleaning the dishes that were earlier purchased to facilitate working and studying are now to be procured within the house. Furthermore, the activities like laundry and cleaning the house which were earlier performed by domestic workers for a wage while the members of the household were allocating the same time for other activities, for example, preparing for office, are now to be performed by the members of the household at a time that does not conflict with the office hours. Thus, the norms of work from home and online education increased the demand for services that were earlier purchased both within and outside the household, and are to be now performed without pay during the lockdown, therefore increasing the burden of unpaid work which is gendered in nature.

As Amrita, ${ }^{12}$ a 48 -year old homemaker and a mother of two adults who reported to work for more than $70 \mathrm{~h}$ /work during the lockdown states,
"Before the lockdown, I was living with my husband and my son and my daughter was staying away to pursue her education and later job. The lock down has permanently moved all their work to home. I cook for all of them which takes longer than earlier. But cooking is not the most time-consuming activity. With four of us living in the house all the time, cleaning the dishes has to be done multiple times during the day."

Akriti, a 28-year old single woman working in Delhi, who has moved back to her hometown in Uttar Pradesh and reported spending a maximum of $7 \mathrm{~h} /$ week on unpaid work during the lockdown narrates,

"Work from home has increased my working hours. The concept of weekend has almost collapsed with my organization assuming that work from home means being available $24 \times 7$. And with no domestic help, it was getting very difficult for me to manage professional space and household chores. So, I came back home at the first opportunity. Now cooking and food needs are taken care of by my mother, and I can focus on my job."

Meera, a 43-year old woman, who is married and is working in an IT firm and has two school going children, has to spend more time with her children during their online classes, cater to their personal needs and also keep them constantly engaged in fun activities as they cannot go to public places to play anymore. She states,

"With schools being shut and education being done through online mode, I have to constantly look after my children, get involved in their virtual classes and also do my office work. In the pre-COVID world, we all used to spend time together in the evening, and go out on weekends. Now, I have to devote a lot more time to child care. It has started affecting my professional life as I am

12 Names of the interviewees have been changed for the purpose of privacy and anonymity. 
missing deadlines and am constantly tired. My husband is a big support, but his working hours are more rigid than mine."

\section{Sanitization and Hygiene: The Load of New Activities}

Another manifestation of the lockdown is visible in the recurring need to maintain social distancing and hygiene through sanitising everything that has physically been in the public space, which has created a new set of activities that need to be performed daily and are time consuming. As Amrita states,

"Since the onset of the pandemic, I sanitize all the vegetables and grocery items that are purchased for the household. Other than that, I separately wash and sanitize all the footwear and clothes that are used while going to the supermarket."

Akriti highlights a similar concern and narrates,

"The pandemic has created so much extra work in terms of sanitizing everything from milk packets to vegetables and fruits. After buying vegetables and fruits we soak them in a tub of water for about $2-3 \mathrm{~h}$, then wipe them with a sanitized cloth, and then use for consumption. It is time-consuming considering we are a family of five people."

Not only this, the pandemic has also created the need to boost immunity and promote intake of herbal products or home-made kadha. This has also added to the burden of the unpaid household chores. As Meera states,

"I make sure all of us consume kadha two times a day. We have also increased consumption of Indian herbs and immunity boosting products like cinnamon, raw turmeric, basil, ginger and honey, and we either consume it with milk, tea or make a paste of some of it. As me and my husband are particularly concerned about the well-being of our children, we make sure that we buy it only in solid form and grind it at home to get a powdered form. It has added to some of my original kitchen work, but I think this is inevitable."

In her interview, Akriti also highlighted the increase in care work due to probable COVID-19 suspect at home that increased everyone's time spent at home, but more so of the mother in the kitchen work. As stated by her:

"The assumption that my brother might be infected with COVID-19 increased all our workloads, and most of all my mother's. She was making him kadha, boiling water for the purpose of steaming and drinking, making separate immunity boosting food items for him, serving him food, cleaning his clothes and maintaining everything related to his cleanliness and hygiene. Plus, she was also regularly monitoring his overall health and her own health in isolation to all of us, in case the infection spread to her as well. Me and my dad were busy procuring medicines, consulting doctors, and preparing for the day if things got worse." 
The requirements to maintain social distancing and hygiene in the pandemic, has also led to procuring luxury eating and leisure eating within the house that was earlier done in restaurants and was paid for. As Rita, a 35-year old school teacher who lives with her husband and has school going child highlights:

"I love eating out. Before the onset of the pandemic, all of us would go out every weekend and try some new food or place to eat. With the lockdown, my daughter and my husband crave for that kind of food, so I cook it at home. During the first month of the lockdown itself, I made gulab jamun thrice, samosas twice and other items like chilli potatoes, rasgullas, momos, barfi, cakes and brownies."

\section{Perceptions and Gender Roles}

An examination of the perception regarding gender roles and the responsibility of unpaid work highlighted that while none of the interviewees believed that women are more responsible for household chores than men just because of their gender, two observations are significant in this context. First, is the fixation on unemployed women who are housewives/homemakers to share a greater burden of household chores for every member in the family. The reason most cited for this is that since these women are not engaged in any type of income generating activities, they have more time available to perform the domestic work. In addition, the interviewees also stated that since other members of the household are working full time, they do not have any spare time to contribute to domestic chores, which are therefore inadvertently taken up by the unemployed women of the house, either mothers or wives. This has been observed in the interviews with both men and women. As Amrita states,

"All the other members of my family are working full-time jobs and do not have much time available to help me with household chores. So, they help me as and when they can. I am a housewife, it is my responsibility to keep the house running. And the house will come to a halt if I stop doing the domestic work."

Aman, a 28-year old single working professional states that,

"The lockdown has increased all our work at home, particularly so for my mother. But considering that she is a homemaker, she was already doing many of these chores even before the pandemic. I try to help her as much as I can, particularly with work that is more physically demanding like cleaning the house. But I cannot take full time responsibility of running the house as I have professional commitments as well."

Second, is the inefficiency argument where the interviewees have stated that they do not contribute much to the household as they take longer to perform the same activity as compared to other member of the household who is more responsible for the domestic work. 


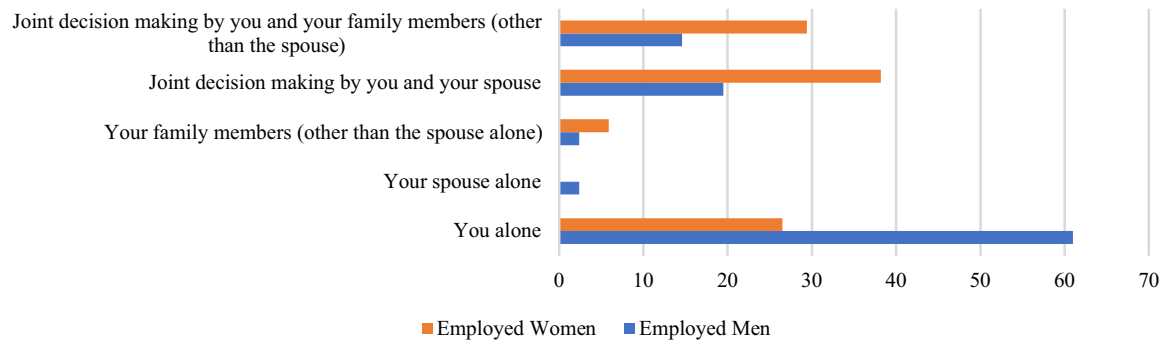

Fig. 9 Employment related decision-making

Akshay, a 53-year old working man, who lives with his wife, son and daughter states that,

"I do not think that women are more responsible for running the house because of their gender. I can pursue all the household activities on my own including cooking, cleaning the house, laundry and doing the dishes. But I have not done these things for a long time on regular basis. I take much longer than my wife to complete the same household chores."

Similar perceptions have been observed in interviews with both men and women. However, the inefficiency argument is just an extension of the gender roles and norms which have to be fulfilled with the performance of certain activities like domestic work. Since, women have been fulfilling these roles and responsibilities even in normal situations before the pandemic set in, they are more efficient at these activities as compared to individuals, generally men, who are new at these activities during the lockdown.

Related with this are the results around the independence in taking employment related decisions. As shown in Fig. 9, for employed respondents, approximately $61 \%$ of employed men take such decisions by themselves as compared to only $26 \%$ employed women. Furthermore, approximately $67 \%$ employed women's work-related decision making is influenced by the spouse and family members as compared to only $34 \%$ employed men. This is indicative that men have relatively more control and independence in decision making related to employment as compared to women who are more influenced by their family. This becomes significant, considering that time spent on paid work and the inefficiency argument is an important determinant of the burden of unpaid work shared in the household as is highlighted above. Gender norms and roles are therefore constantly working and making women share a greater burden of unpaid work.

However, there is also a growing perception where it is acknowledged that men and women should equally share the burden of unpaid work. As Ritu, a 35-year old working woman living with her husband and a 2-year old kid states:

"I don't think that me being a woman is enough for me to contribute more to the household. My husband and I are both working, and live in the same house, so we share the tasks based on our interests and work hours, and also help each other in case there are some other engagements, particularly at work 
place. Since my husband's organization is more flexible and sensitive to the changing needs of the work from home as compared to mine, I feel he ends up doing my share of the work too some times. Overall, we share the load."

Similarly, Rajeev, a 27-year old married man and an IT Manager narrates,

"Me and my wife are engaged in full-time jobs and have similar commitments at work place. Plus, we both have been raised in similar ways where we were not responsible for managing domestic chores. The lockdown has confined us to the household with no domestic help. We help each other with all the household tasks. I cook and my wife takes care of buying the groceries and cleaning the house. When I have full-day meetings, then she supports me with cooking too."

Similar perceptions regarding sharing of household chores were observed among other respondents, particularly among married individuals where their partner is also engaged in full-time employment. None of the interviewees endorsed women quitting their jobs to take greater responsibility of unpaid household chores that had increased manifold during the lockdown. This, therefore, creates an opportunity to bring a change in gender norms regarding unpaid household chores, particularly when women are engaged in full-time employment and are financially independent. However, such perceptions are limited to individuals where all their household members are employed. In households where one or more member is unemployed, the interviewees suggested that the unemployed member, generally a woman (housewife/homemaker), should take up greater burden of unpaid work.

\section{Conclusion}

This paper highlights the impact of COVID-19 on gender equality, specifically on the burden of unpaid work for women. The paper shows that women were already sharing a higher burden of unpaid work, and COVID-19 and the consequent lockdown has worked to exacerbate the existing gender inequalities and increased their burden of unpaid work even more. Among women, marital status and employment status are the key determinants of women's burden of unpaid work where time spent on unpaid work has increased the highest for married women and unemployed women, who were already spending the highest time on such work even before the lockdown. Specifically, during the lockdown, approximately $22.5 \%$ of married women, as compared to zero men and unmarried women, worked for more than $70 \mathrm{~h} /$ week. Similarly, unemployed women witness the highest increase of 30.5 percentage points for those who spent more than $70 \mathrm{~h} /$ week on unpaid work as compared to employed women who show the highest increase of 14.7 percentage points for those spending 22-28 h/week and 29-49 h/week each. The emerging norms of work from home and online education, and the new needs of sanitization are responsible for the increased burden. For unemployed women, particularly the housewives/homemakers, the excessive burden is due to the perception that their share of responsibility 
for unpaid work should be more due to not being engaged in full-time employment and is more efficient in performing these tasks. As such, unemployed women have to perform the unpaid domestic work for all members of the household. For employed women, the collapse of the distinction of the professional and personal lives, both of which are now confined to the household, means that office commitments and domestic responsibilities are to be fulfilled simultaneously. This has created time poverty for most women which impacts their opportunities for engaging in employment, professional performance, career advancement, and leisure, thereby affecting their overall well-being and empowerment. In the context of perceptions regarding gender roles for unpaid work, while it was found that individuals did not overtly believe in putting the burden on women by the virtue of their gender, but rationalized it with the time spent on full-time paid work (for unemployed women) and their own inefficiencies in performing such tasks. In addition, the results on employment related decision-making shows that gender roles and responsibilities, though overtly rejected, remain entrenched in the social norms of the society. However, there is a ray of hope in reversing gender roles in the household work during the pandemic as both men and women are looking for gender equality in performing unpaid work, particularly when all members of the household are engaged in full-time employment. For this, it is suggested that the work from home norms and online education becomes more flexible and suits requirements of the employees. Furthermore, such flexibility needs to be extended not only to women, but also to men to facilitate their contribution in the unpaid domestic work. However, caution should be exercised in terms of policy making as flexibility in working will not automatically translate into gender equality in unpaid work and will have to be catalysed through awareness, knowledge and opportunities. Finally, the new norms of work and related policy, by both the government and the private players should focus on gender mainstreaming, ${ }^{13}$ where gender perspectives are integrated into the designing, implementation, and monitoring and evaluation of policies, rather than addressing these concerns in isolation.

Acknowledgements I thank my supervisor, Prof. Amita Batra, Chairperson, Centre for South Asian Studies, Jawaharlal Nehru University for her support and guidance. I also thank Pratiksha Singh, Parvendra Kumar, Prayrit and Kaushik for their support and assistance. I also extend my gratitude to all the individuals who participated in the survey and interviews. Please note that this research has not received any external funding.

Funding The research has not received any external funding.

Data Availability The data have been collected through surveys and interviews, as is provided in the manuscript.

\footnotetext{
13 In July 1997, the United Nations Economic and Social Council (ECOSOC) define the concept of gender mainstreaming as: "Mainstreaming a gender perspective is the process of assessing the implications for women and men of any planned action, including legislation, policies and programmes, in any area and at all levels" and "is a strategy for making the concerns and experiences of women as well as of men an integral part of the design, implementation, monitoring and evaluation of policies and programmes in all political, economic and societal spheres so that women and men benefit equally, and inequality is not perpetuated"[16].
} 


\section{Compliance with Ethical Standards}

Conflict of interest The author declares that there is no conflict of interest.

Consent to Participate Informed consent was obtained from all individual participants included in the study. The survey respondents had consented to their data being used for the purpose of the study and verbal informed consent was obtained prior to the interview.

Consent to Publish Participants have consented to the submission of the case report to the journal. However, names of the interviewees have been changed for the purpose of anonymity with the consent of the participants.

\section{Appendix: Summary of the Survey Results}

See Tables 3, 4, 5, 6, 7, 8, 9, 10 and 11.

Table 3 Gender-wise time spent on unpaid work

Table 4 Time spent on unpaid work for married respondents

\begin{tabular}{|c|c|c|c|c|}
\hline \multirow{2}{*}{$\begin{array}{l}\text { Time spent on } \\
\text { unpaid work (h/ } \\
\text { week) }\end{array}$} & \multicolumn{2}{|c|}{ Before the lockdown } & \multicolumn{2}{|c|}{ During the lockdown } \\
\hline & $\begin{array}{l}\text { Number } \\
\text { of men }\end{array}$ & $\begin{array}{l}\text { Number of } \\
\text { women }\end{array}$ & $\begin{array}{l}\text { Number } \\
\text { of men }\end{array}$ & $\begin{array}{l}\text { Number } \\
\text { of women }\end{array}$ \\
\hline $0-7$ & 29 & 26 & 17 & 11 \\
\hline $8-14$ & 11 & 10 & 10 & 7 \\
\hline $15-21$ & 2 & 6 & 9 & 10 \\
\hline $22-28$ & 0 & 3 & 4 & 9 \\
\hline $29-49$ & 1 & 7 & 2 & 6 \\
\hline $50-70$ & 0 & 4 & 1 & 5 \\
\hline$>70$ & 0 & 1 & 0 & 9 \\
\hline Total & 43 & 57 & 43 & 57 \\
\hline
\end{tabular}

\begin{tabular}{|c|c|c|c|c|}
\hline \multirow{2}{*}{$\begin{array}{l}\text { Time spent on } \\
\text { unpaid work (h/ } \\
\text { week) }\end{array}$} & \multicolumn{2}{|c|}{ Before the lockdown } & \multicolumn{2}{|c|}{ During the lockdown } \\
\hline & $\begin{array}{l}\text { Number } \\
\text { of men }\end{array}$ & $\begin{array}{l}\text { Number of } \\
\text { women }\end{array}$ & $\begin{array}{l}\text { Number } \\
\text { of men }\end{array}$ & $\begin{array}{l}\text { Number } \\
\text { of women }\end{array}$ \\
\hline $0-7$ & 22 & 15 & 13 & 6 \\
\hline $8-14$ & 10 & 5 & 6 & 2 \\
\hline $15-21$ & 2 & 5 & 9 & 6 \\
\hline $22-28$ & 0 & 3 & 4 & 6 \\
\hline $29-49$ & 1 & 7 & 2 & 6 \\
\hline $50-70$ & 0 & 4 & 1 & 5 \\
\hline$>70$ & 0 & 1 & 0 & 9 \\
\hline Total & 35 & 40 & 35 & 40 \\
\hline
\end{tabular}


Table 5 Time spent on unpaid work for unmarried respondents

Table 6 Time spent on unpaid work for employed respondents

Table 7 Time spent on unpaid work for unemployed respondents

\begin{tabular}{|c|c|c|c|c|}
\hline \multirow{2}{*}{$\begin{array}{l}\text { Time spent on } \\
\text { unpaid work (h/ } \\
\text { week) }\end{array}$} & \multicolumn{2}{|c|}{ Before the lockdown } & \multicolumn{2}{|c|}{ During the lockdown } \\
\hline & $\begin{array}{l}\text { Number } \\
\text { of men }\end{array}$ & $\begin{array}{l}\text { Number of } \\
\text { women }\end{array}$ & $\begin{array}{l}\text { Number } \\
\text { of men }\end{array}$ & $\begin{array}{l}\text { Number } \\
\text { of women }\end{array}$ \\
\hline $0-7$ & 7 & 11 & 4 & 5 \\
\hline $8-14$ & 1 & 5 & 4 & 5 \\
\hline $15-21$ & 0 & 1 & 0 & 4 \\
\hline $22-28$ & 0 & 0 & 0 & 3 \\
\hline $29-49$ & 0 & 0 & 0 & 0 \\
\hline $50-70$ & 0 & 0 & 0 & 0 \\
\hline$>70$ & 0 & 0 & 0 & 0 \\
\hline Total & 8 & 17 & 8 & 17 \\
\hline
\end{tabular}

\begin{tabular}{|c|c|c|c|c|}
\hline \multirow{2}{*}{$\begin{array}{l}\text { Time spent on } \\
\text { unpaid work (h/ } \\
\text { week) }\end{array}$} & \multicolumn{2}{|c|}{ Before the lockdown } & \multicolumn{2}{|c|}{ During the lockdown } \\
\hline & $\begin{array}{l}\text { Number } \\
\text { of men }\end{array}$ & $\begin{array}{l}\text { Number of } \\
\text { women }\end{array}$ & $\begin{array}{l}\text { Number } \\
\text { of men }\end{array}$ & $\begin{array}{l}\text { Number } \\
\text { of women }\end{array}$ \\
\hline $0-7$ & 28 & 19 & 16 & 6 \\
\hline $8-14$ & 11 & 8 & 10 & 5 \\
\hline $15-21$ & 1 & 4 & 9 & 8 \\
\hline $22-28$ & 0 & 2 & 4 & 7 \\
\hline 29-49 & 1 & 1 & 1 & 6 \\
\hline $50-70$ & 0 & 0 & 1 & 1 \\
\hline$>70$ & 0 & 0 & 0 & 1 \\
\hline Total & 41 & 34 & 41 & 34 \\
\hline
\end{tabular}

\begin{tabular}{|c|c|c|c|c|}
\hline \multirow{2}{*}{$\begin{array}{l}\text { Time spent on } \\
\text { unpaid work (h/ } \\
\text { week) }\end{array}$} & \multicolumn{2}{|c|}{ Before the lockdown } & \multicolumn{2}{|c|}{ During the lockdown } \\
\hline & $\begin{array}{l}\text { Number } \\
\text { of men }\end{array}$ & $\begin{array}{l}\text { Number of } \\
\text { women }\end{array}$ & $\begin{array}{l}\text { Number } \\
\text { of men }\end{array}$ & $\begin{array}{l}\text { Number } \\
\text { of women }\end{array}$ \\
\hline $0-7$ & 1 & 7 & 1 & 5 \\
\hline $8-14$ & 0 & 2 & 0 & 2 \\
\hline $15-21$ & 1 & 2 & 0 & 2 \\
\hline $22-28$ & 0 & 1 & 1 & 2 \\
\hline $29-49$ & 0 & 6 & 0 & 0 \\
\hline $50-70$ & 0 & 4 & 0 & 4 \\
\hline$>70$ & 0 & 1 & 0 & 8 \\
\hline Total & 2 & 23 & 2 & 23 \\
\hline
\end{tabular}


Table 8 Time spent on unpaid work based on monthly income before the lockdown

\begin{tabular}{|c|c|c|c|c|c|c|c|c|}
\hline \multirow{2}{*}{$\begin{array}{l}\text { Time spent on } \\
\text { unpaid work (h/ } \\
\text { week) }\end{array}$} & \multicolumn{2}{|c|}{$<25,000$ INR } & \multicolumn{2}{|c|}{$\begin{array}{l}25,000-50,000 \\
\text { INR }\end{array}$} & \multicolumn{2}{|c|}{$\begin{array}{l}50,000-100,000 \\
\text { INR }\end{array}$} & \multicolumn{2}{|c|}{$>100,000$ INR } \\
\hline & $\begin{array}{l}\text { Num- } \\
\text { ber of } \\
\text { men }\end{array}$ & $\begin{array}{l}\text { Num- } \\
\text { ber of } \\
\text { women }\end{array}$ & $\begin{array}{l}\text { Num- } \\
\text { ber of } \\
\text { men }\end{array}$ & $\begin{array}{l}\text { Num- } \\
\text { ber of } \\
\text { women }\end{array}$ & $\begin{array}{l}\text { Num- } \\
\text { ber of } \\
\text { men }\end{array}$ & $\begin{array}{l}\text { Num- } \\
\text { ber of } \\
\text { women }\end{array}$ & $\begin{array}{l}\text { Num- } \\
\text { ber of } \\
\text { men }\end{array}$ & $\begin{array}{l}\text { Number } \\
\text { of womer }\end{array}$ \\
\hline $0-7$ & 3 & 2 & 7 & 4 & 6 & 7 & 12 & 6 \\
\hline $8-14$ & 0 & 1 & 0 & 1 & 7 & 4 & 4 & 2 \\
\hline $15-21$ & 0 & 0 & 0 & 3 & 1 & 0 & 0 & 1 \\
\hline $22-28$ & 0 & 1 & 0 & 0 & 0 & 1 & 0 & 0 \\
\hline $29-49$ & 0 & 0 & 1 & 1 & 0 & 0 & 0 & 0 \\
\hline $50-70$ & 0 & 0 & 0 & 0 & 0 & 0 & 0 & 0 \\
\hline$>70$ & 0 & 0 & 0 & 0 & 0 & 0 & 0 & 0 \\
\hline Total & 3 & 4 & 8 & 9 & 14 & 12 & 16 & 9 \\
\hline
\end{tabular}

Table 9 Time spent on unpaid work based on monthly income after the lockdown

\begin{tabular}{|c|c|c|c|c|c|c|c|c|}
\hline \multirow{2}{*}{$\begin{array}{l}\text { Time spent on } \\
\text { unpaid work (h/ } \\
\text { week) }\end{array}$} & \multicolumn{2}{|c|}{$<25,000 \mathrm{INR}$} & \multicolumn{2}{|c|}{$\begin{array}{l}25,000-50,000 \\
\text { INR }\end{array}$} & \multicolumn{2}{|c|}{$\begin{array}{l}50,000-100,000 \\
\text { INR }\end{array}$} & \multicolumn{2}{|c|}{$>100,000 \mathrm{INR}$} \\
\hline & $\begin{array}{l}\text { Num- } \\
\text { ber of } \\
\text { men }\end{array}$ & $\begin{array}{l}\text { Num- } \\
\text { ber of } \\
\text { women }\end{array}$ & $\begin{array}{l}\text { Num- } \\
\text { ber of } \\
\text { men }\end{array}$ & $\begin{array}{l}\text { Num- } \\
\text { ber of } \\
\text { women }\end{array}$ & $\begin{array}{l}\text { Num- } \\
\text { ber of } \\
\text { men }\end{array}$ & $\begin{array}{l}\text { Num- } \\
\text { ber of } \\
\text { women }\end{array}$ & $\begin{array}{l}\text { Num- } \\
\text { ber of } \\
\text { men }\end{array}$ & $\begin{array}{l}\text { Number } \\
\text { of womer }\end{array}$ \\
\hline $0-7$ & 2 & 0 & 4 & 2 & 4 & 3 & 6 & 1 \\
\hline $8-14$ & 0 & 1 & 2 & 1 & 5 & 3 & 3 & 0 \\
\hline $15-21$ & 0 & 1 & 1 & 1 & 2 & 1 & 6 & 5 \\
\hline $22-28$ & 0 & 2 & 0 & 1 & 3 & 1 & 1 & 3 \\
\hline $29-49$ & 1 & 0 & 0 & 3 & 0 & 3 & 0 & 0 \\
\hline $50-70$ & 0 & 0 & 1 & 1 & 0 & 0 & 0 & 0 \\
\hline$>70$ & 0 & 0 & 0 & 0 & 0 & 1 & 0 & 0 \\
\hline Total & 3 & 4 & 8 & 9 & 14 & 12 & 16 & 9 \\
\hline
\end{tabular}

Table 10 Time spent on unpaid work based on average weekly office hours before the lockdown

\begin{tabular}{|c|c|c|c|c|c|c|}
\hline \multirow{2}{*}{$\begin{array}{l}\text { Time spent on unpaid } \\
\text { work (h/week) }\end{array}$} & \multicolumn{2}{|l|}{$<25 \mathrm{~h} /$ week } & \multicolumn{2}{|c|}{ 25-48 h/week } & \multicolumn{2}{|l|}{$>48 \mathrm{~h} /$ week } \\
\hline & $\begin{array}{l}\text { Number of } \\
\text { men }\end{array}$ & $\begin{array}{l}\text { Number of } \\
\text { women }\end{array}$ & $\begin{array}{l}\text { Number of } \\
\text { men }\end{array}$ & $\begin{array}{l}\text { Number of } \\
\text { women }\end{array}$ & $\begin{array}{l}\text { Number of } \\
\text { men }\end{array}$ & $\begin{array}{l}\text { Number } \\
\text { of women }\end{array}$ \\
\hline $0-7$ & 2 & 3 & 12 & 7 & 14 & 9 \\
\hline 8-14 & 1 & 3 & 4 & 3 & 6 & 2 \\
\hline $15-21$ & 0 & 0 & 0 & 2 & 1 & 2 \\
\hline $22-28$ & 0 & 0 & 0 & 1 & 0 & 1 \\
\hline $29-49$ & 0 & 0 & 1 & 0 & 0 & 1 \\
\hline $50-70$ & 0 & 0 & 0 & 0 & 0 & 0 \\
\hline$>70$ & 0 & 0 & 0 & 0 & 0 & 0 \\
\hline Total & 3 & 6 & 17 & 13 & 21 & 15 \\
\hline
\end{tabular}


Table 11 Time spent on unpaid work based on average weekly office hours after the lockdown

\begin{tabular}{|c|c|c|c|c|c|c|}
\hline \multirow{2}{*}{$\begin{array}{l}\text { Time spent on unpaid } \\
\text { work (h/week) }\end{array}$} & \multicolumn{2}{|c|}{$<25 \mathrm{~h} /$ week } & \multicolumn{2}{|c|}{$25-48 \mathrm{~h} /$ week } & \multicolumn{2}{|c|}{$>48 \mathrm{~h} /$ week } \\
\hline & $\begin{array}{l}\text { Number of } \\
\text { men }\end{array}$ & $\begin{array}{l}\text { Number of } \\
\text { women }\end{array}$ & $\begin{array}{l}\text { Number of } \\
\text { men }\end{array}$ & $\begin{array}{l}\text { Number of } \\
\text { women }\end{array}$ & $\begin{array}{l}\text { Number of } \\
\text { men }\end{array}$ & $\begin{array}{l}\text { Number } \\
\text { of women }\end{array}$ \\
\hline $0-7$ & 2 & 0 & 9 & 2 & 5 & 4 \\
\hline $8-14$ & 1 & 1 & 4 & 2 & 5 & 2 \\
\hline $15-21$ & 0 & 2 & 3 & 3 & 6 & 3 \\
\hline $22-28$ & 0 & 2 & 0 & 3 & 4 & 2 \\
\hline $29-49$ & 0 & 0 & 1 & 2 & 1 & 4 \\
\hline $50-70$ & 0 & 0 & 0 & 1 & 0 & 0 \\
\hline$>70$ & 0 & 1 & 0 & 0 & 0 & 0 \\
\hline Total & 3 & 6 & 17 & 13 & 21 & 15 \\
\hline
\end{tabular}

\section{References}

1. Action Aid. (2019). Invisible work invisible workers: The sub-economies of unpaid work and paid work action research on women's unpaid labour. Johannesburg: Action Aid.

2. Agarwal, B. (1997). "Bargaining" and gender relations: Within and beyond the household. Feminist Economics, 3(1), 1-51.

3. Alon, T. M., Doepke, M., Olmstead-Rumsey, J., \& Tertilt, M. (2020). The impact of COVID-19 on gender equality. Cambridge: National Bureau of Economic Research.

4. Becker, G. S. (1976). Altruism, egoism, and genetic fitness: Economics and sociobiology. Journal of Economic Literature, 14(3), 817-826.

5. Bittman, M., England, P., Sayer, L., Folbre, N., \& Matheson, G. (2003). When does gender trump money? Bargaining and time in household work. American Journal of Sociology, 109(1), 186-214.

6. Brines, J. (1994). Economic dependency, gender, and the division of labor at home. American Journal of Sociology, 100(3), 652-688.

7. Coffey, C., Revollo, P. E., Harvey, R., Lawson, M., Butt, A. P., Piaget, K., et al. (2020). Time to care: Unpaid and underpaid care work and the global inequality crisis. Nairobi: Oxfam International.

8. Doss, C. (2013). Intrahousehold bargaining and resource allocation in developing countries. The World Bank Research Observer Special Issue on Gender Equality and Development, 28(1), 52-78.

9. Dutta, D. (2019). No work is easy! Notes from the field on unpaid care work for women. In O. India (Ed.), Mind the gap: The state of employment in India (pp. 98-125). New Delhi: Oxfam India.

10. Ferrant, G., Pesando, L. M., \& Nowacka, K. (2014). Unpaid care work: The missing link in the analysis of gender gaps in labour outcomes. Paris: OECD Development Centre.

11. Frankiewicz, B. (2020). 5 ways we lack gender balance in the workplace. World Economic Forum. https://www.weforum.org/agenda/2020/01/5-ways-companies-can-progress-more-women-intoleadership-roles/. Retrieved July 15, 2020.

12. Greenstein, T. N. (2000). Economic dependence, gender, and the division of labor in the home: A replication and extension. Journal of Marriage and Family, 62(2), 322-335.

13. Grown, C., \& Sánchez-Páramo, C. (2020). The coronavirus is not gender-blind, nor should we be. World Bank Blogs. https://blogs.worldbank.org/voices/coronavirus-not-gender-blind-nor-shoul d-we-be. Retrieved July 15, 2020.

14. Hirway, I. (2012). Missing labour force: An explanation. Economic and Political Weekly, 47(37), 67-72.

15. International Labour Organization (ILO). (2018). Care work and care jobs for the future of decent work (p. 40). Geneva: ILO.

16. International Labour Organization (ILO). (n.d.). Gender equality tool. ILO. https://www.ilo.org/ public/english/bureau/gender/newsite2002/about/defin.htm. Retrieved September 21, 2020.

17. Katz, E. (1997). The intra-household economics of voice and exit. Feminist Economics, 3(3), 25-46. 
18. McGinnity, F., \& Russell, H. (2008). Gender inequalities in time use the: Distribution of caring, housework and employment among women and men in Ireland. Dublin: The Equality Authority and The Economic and Social Research Institute.

19. Moser, C. O. (1993). Gender planning and development: Theory, practice and training. London and New York: Routledge.

20. OECD. (n.d.). OECD.Stat. Employment: Time spent in paid and unpaid work, by sex. Retrieved July 3, 2020, from https://stats.oecd.org/index.aspx?queryid=54757.

21. Oláh, L. S., \& Gähler, M. (2014). Gender equality perceptions, division of paid and unpaid work, and partnership dissolution in Sweden. Social Forces, 93(2), 571-594.

22. Quisumbing, A. R. (2003). What have we learned from research on intrahousehold allocation? In A. R. Quisumbing (Ed.), Household decisions, gender, and development: A synthesis of recent research (pp. 1-22). Washington, D.C.: International Food Policy Research Institute.

23. Rathgeber, E. M. (1990). WID, WAD, GAD: Trends in research and practice. The Journal of Developing Areas, 24(4), 489-502.

24. Sayer, L. C. (2005). Gender, time and inequality: Trends in women's and men's paid work, unpaid work and free time. Social Forces, 84(1), 285-303.

25. United Nations. (2020). The impact of COVID-19 on women. New York: United Nations.

26. Vijaya, R., Lahoti, R., \& Swaminathan, H. (2013). Moving from the household to the individual: Multidimensional poverty analysis. World Development, 59, 70-81.

27. West, C., \& Zimmerman, D. H. (1987). Doing gender. Gender and Society, 1(2), 125-151.

28. World Bank. (2020). Gender dimensions of the COVID-19 pandemic. Washington: World Bank.

29. World Bank. (n.d.). The World Bank Data. Labor force participation rate, female (\% of female population ages 15+) (modeled ILO estimate)—India. https://data.worldbank.org/indicator/SL.TLF. CACT.FE.ZS?locations=IN. Retrieved July 15, 2020.

Publisher's Note Springer Nature remains neutral with regard to jurisdictional claims in published maps and institutional affiliations. 